\title{
Survey of rickettsiae in humans, dogs, horses, and ticks in Northern Paraná, Brazil
}

\section{Levantamento de riquétsias em humanos, cães, cavalos e carrapatos no Norte do Paraná, Brasil}

\author{
Katia Tamekuni ${ }^{1}$; Roberta dos Santos Toledo ${ }^{1}$; Mauro de Freitas Silva Filho \\ Valeska Bender Haydu²; Richard Campos Pacheco ${ }^{3}$; Marcelo Bahia Labruna ${ }^{4}$; John \\ Stephen Dumler ${ }^{5}$; Odilon Vidotto ${ }^{6 *}$
}

\begin{abstract}
Brazilian Spotted Fever is a disease caused by Rickettsia rickettsii, and is transmitted to humans and animals by Amblyomma spp. The objective of this work was to study the epidemiology of spotted fever group rickettsiae in rural areas of Northern Parana. In Alvorada do Sul municipality, 88 humans, 83 dogs, and 18 horses were sampled, and in Arapongas municipality, 138 humans, 90 dogs and 18 horses were studied. All the sera were tested by IFA in which $R$. rickettsii and $R$. parkeri were used as antigens, considering titers $\geq 64$ positive. Ticks collected from dogs and horses were tested by PCR. In Alvorada do Sul, $24 \%$ and $16.1 \%$ of humans, $55.6 \%$ and $22.2 \%$ of horses and, $22.9 \%$ and $18.1 \%$ of dogs were seropositive for $R$ rickettsii and $R$. parkeri, respectively. In Arapongas, $9.4 \%$ and $4.3 \%$ of the humans, $5.6 \%$ and $5.6 \%$ of horses and, $13.3 \%$ and $12.2 \%$ of the dogs were seropositive for $R$. rickettsii and $R$. parkeri, respectively. PCR detected seven ticks with gltA sequences that showed similarity with $R$. bellii. The presence of antibodies to $R$. parkeri and $R$. rickettsii in dogs, horses and humans demonstrates a potential risk for spotted fever group rickettsiae in these areas.
\end{abstract}

Key words: Rickettsia spp., brazilian spotted fever, Amblyomma spp., epidemiology

\section{Resumo}

Febre Maculosa Brasileira é uma doença causada por Rickettsia rickettsii, e é transmitida para humanos e animais por Amblyomma spp. O objetivo deste trabalho foi estudar a epidemiologia de riquétsias do grupo da febre em áreas rurais do Norte do Paraná. No município de Alvorada do Sul, 88 pessoas, 83 cães e 18 cavalos foram amostrados, e no município de Arapongas, 138 seres humanos, 90 cães e 18 cavalos foram estudados. Todos os soros foram testados por IFI com $R$. rickettsii e $R$. parkeri como antígenos, considerando-se os títulos $\geq 64$ positivos. Carrapatos coletados de cães e cavalos foram testados por PCR. Em Alvorada do Sul, $24 \%$ e $16,1 \%$ dos seres humanos, $55,6 \%$ e $22,2 \%$ de cavalos e, $22,9 \%$ e $18,1 \%$ de cães foram soropositivos para $R$. rickettsii e $R$. parkeri, respectivamente. Em Arapongas, 9,4\% e 4,3\% dos seres humanos, $5,6 \%$ e 5,6\% de cavalos e, $13,3 \%$ e $12,2 \%$ dos cães foram soropositivos para $R$. rickettsii

\footnotetext{
Programa de Pós-Graduação em Ciência Animal, Universidade Estadual de Londrina, UEL, Campus Universitário, C P 6001. 86051-990, Londrina, PR. E-mail: katiatamekuni@gmail.com; betatoledo@yahoo.com.br; maurobtos@pop.com.br

2 Residência em Medicina Veterinária Preventiva, Hospital Escola Veterinário, UEL, Londrina, PR. E-mail: valeska_haydu@ hotmail.com

3 Faculdade de Agronomia e Medicina Veterinária, Universidade Federal do Mato Grosso, Cuiabá. E-mail: richard@ufmt.br

4 Departamento de Medicina Veterinária Preventiva e Saúde Animal, Universidade de São Paulo, SP. E-mail: labruna@usp.br

5 Department of Pathology, The Johns Hopkins University School of Medicine, Baltimore, MD, USA. E-mail: sdumler@jhmi.edu

6 Prof. Dr. do Departamento de Medicina Veterinária Preventiva, UEL, Londrina, PR. E-mail: vidotto@uel.br

* Correponding autor
} 
e $R$. parkeri, respectivamente. A PCR detectou 7 carrapatos com seqüências gltA que mostrou semelhança com $R$. bellii. A presença de anticorpos para $R$. rickettsii e $R$. parkeri em cães, cavalos e seres humanos demonstra um risco potencial para riquétsias do grupo da febre maculosa nestas áreas.

Palavras-chave: Rickettsia spp, febre maculosa brasileira, Amblyomma spp, epidemiologia

\section{Introduction}

Spotted Fever Rickettsia infections are acute febrile tick-borne diseases caused by bacteria of the genus Rickettsia, which belong to the order and Rickettsiaceae family (DUMLER et al., 2001). Rickettsiae are obligatory intracellular, Gramnegative bacteria, which have been classically classified into two groups: the typhus group (TG) and the spotted fever group (SFG). The TG is composed by 2 species, $R$. prowazekii and $R$. typhi, while the SFG is composed by many species, for which many are considered of variable pathogenicity in humans (HOOGSTRAAL, 1985; RAOULT; ROUX, 1997). R. rickettsii, the most pathogenic SFG species, is the etiological agent of Brazilian spotted fever in Brazil (BSF).

In Brazil, Amblyomma spp. ticks are the main vectors of $R$. rickettsii to humans and animals (GALVÃO et al., 2003; McDADE; NEWHOUSE, 1986). Amblyomma cajennense is considered the most important vector for transmission to humans (LEMOS et al., 1997, GUEDES et al., 2005), although $A$. aureolatum is also important in a few areas in the state of São Paulo (PINTER; LABRUNA, 2006). Transovarial transmission is an important mechanism for maintaining these rickettsiae in nature (RAOULT; ROUX, 1997). However, $R$. rickettsii is pathogenic for ticks and thus requires amplification through horizontal transmission via vertebrate hosts, in order to create new lineages of infected ticks in nature (McDADE; NEWHOUSE, 1986). Studies in Brazil have showed that both capybaras (Hydrochoerus hydrochoerus) and opossums (Didelphis spp.) are competent amplifier hosts of $R$. rickettsii for A. cajennense ticks (TRAVASSOS; VALLEJOFREIRE, 1942; LABRUNA, 2009).
Recent studies have described other rickettsiae in different areas of Brazil, including R. parkeri, $R$. bellii, R. felis, $R$. amblyommii and $R$. rhipicephali (LABRUNA et al., 2007c; HORTA et al., 2007; SILVEIRA et al., 2007; SAITO et al., 2008). From these above five agents, only $R$. parkeri and $R$. felis are currently recognized as human pathogens (LABRUNA, 2009).

$R$. bellii has been the most common rickettsia found infecting ticks in Brazil, including those tick species more frequently associated with canine and humans infestation, such as A. aureolatum, Amblyomma ovale, Amblyomma oblonguttatum, and Amblyomma scapturatum (LABRUNA et al., 2005, PINTER; LABRUNA, 2006). However, this Rickettsia species are not currently recognized as human or animal pathogen (LABRUNA et al., 2004; 2007a, 2007b).

Epidemiological studies of BSF have shown the importance of dogs and horses to the disease, because dogs carry ticks into human habitations and horses are the major hosts for A. cajennense. Moreover, dogs are secondary hosts for these ticks and like horses, serve as sentinels for rickettsial infection in a given area (LEMOS et al., 1997; LABRUNA et al., 2001; SANGIONI et al., 2005).

The dog tick Rhipicephalus sanguineus, a recognized vector $R$. rickettsii in Mexico and the United States, has deserved more attention in Brazil, where this tick was found naturally infected by $R$. rickettsii in some BSF-endemic areas (LABRUNA, 2009).

In Paraná state, southern Brazil, only two studies of SFG rickettsiosis in humans and animals have been conducted, all in urban areas. In São José dos Pinhais, in the southeast of the state, $9.33 \%$ of horses were seropositive to $R$. rickettsii (FREITAS 
et al., 2010); in Londrina, in the northwest of the state, $4.67 \%$ of humans, $2.74 \%$ of dogs and $38.50 \%$ of horses were seroreactive (TOLEDO et al., 2011).

In the north, Parana State borders with São Paulo State. This later state has many endemic areas for BSF, where many cases of the disease have been noticed since long time ago. Furthermore, in the states of Rio Grande Sul and Santa Catarina, located south to Paraná state, human cases of SFG rickettsiosis have also been confirmed, although the Rickettsia species responsible for these cases have remained unidentified.

The objectives of this work were: a) to evaluate the presence of antibodies against Rickettsia species in humans, dogs and horses in rural communities, in the north of Paraná state; b) to determine risk factors to anti-Rickettsia spp. antibodies; c) to identify Rickettsia species infecting ticks in this region.

\section{Materials and Methods}

\section{Study areas}

Samples were obtained from humans, dogs, and horses in 2 rural areas in the north of Paraná State. Area 1 was located in Alvorada do Sul municipality ( $22^{\circ} 51^{\prime} \mathrm{S} / 51^{\circ} 14^{\prime} \mathrm{W}$ ) and area 2 was in the Arapongas municipality $\left(23^{\circ} 30^{\prime} \mathrm{S} / 51^{\circ} 18^{\prime} \mathrm{W}\right)$. These localities were considered silent for rickettsiosis and the main human activity is agriculture, where families are living in close proximity of dogs and horses. Area 1 occupies 1,068.62 hectares, where 60 families reside. Area 2 has 765.10 hectares with 94 families. These areas have ciliary forests near margins of streams, where there are wild animals.

\section{Samples}

In area 1 , blood samples were obtained from humans, dogs and horses between November 2006 to January 2007, and in area 2, blood samples were obtained from January to March 2007. All samples were collected using sterile materials and labeled before transporting to the laboratory, where the sera were aliquotted and stored at $-20^{\circ} \mathrm{C}$ until used.

Ticks were collected from dogs and horses during the sampling intervals and were maintained in absolute alcohol. Tick species identification followed taxonomic keys (ARAGÃO; FONSECA, 1961; GUIMARÃES; TUCCI; BARROSBATTESTI, 2001).

\section{Indirect immunofluorescence assay (IFA)}

All sera from humans, dogs and horses were tested by IFA, according to Horta et al. (2004), employing two Rickettsia species: $R$. rickettsii strain Taiaçu (PINTER; LABRUNA, 2006) and R. parkeri strain At24 (SILVEIRA et al., 2007). Briefly, Rickettsia species were cultivated in Vero cells until $100 \%$ of cells were infected. Slides were then prepared by harvesting cells and air drying onto multiwell Teflon-coated glass slides, fixed in acetone, and stored at $-20^{\circ} \mathrm{C}$ until used. The slides tested with animal or human sera, followed by respective secondary antibodies, were examined using an epifluorescence microscope (Olympus, Japan). Titers $\geq 64$ were considered positive.

\section{Tick DNA extraction and polymerase chain} reaction ( $P C R)$

DNA extractions were performed according to Chomkzynski (1993) modified by Sangioni et al. (2005). Each tick was dried in sterilized paper, then longitudinally sectioned using sterile scalpel blades, and one portion of the tick was triturated for DNA extraction and the other was stored at $-20^{\circ} \mathrm{C}$.

The PCR assay was performed individually for 101 ticks from dogs and horses located in area 1 and for 31 ticks from area 2. For rickettsial DNA amplification the primers $R p C S .877 \mathrm{p}$ 
(GGGGGCCTGCTCACGGCGG)and $R p C S .1258 \mathrm{n}$ (ATTGCAAAAAGTACAGTGAACA) were used to amplify a 381 base pair region of gltA, which encodes a region of the enzymecitratesynthase found to be efficient to all Rickettsia species (Regnery, Spruill e Plikaytis, 1991). Samples that contained gltA were subsequently tested by PCR using outer membrane protein $\mathrm{A}(\mathrm{omp} A)$ gene primers for the detection of SFG rickettsiae. The primers Rr190.70p (ATGGCGAATATTTCTCCAAAA)

and

Rr190.602n (AGTGCAGCATTCGCTCCCCCT) amplify a 512 bp region of ompA (REGNERY; SPRUILL; PLIKAYTIS, 1991). For the PCR assays, $5 \mu$ l buffer (10X), $5 \mu \mathrm{M}$ for deoxynucleoside triphosphates (dNTP $1.25 \mathrm{mM}$ ), $1.5 \mathrm{mM} \mathrm{MgCl}$ $(50 \mathrm{mM}), 25 \mathrm{pmol}$ of each primer, $1.5 \mathrm{U}$ of Taq DNA polymerase $(5000 \mathrm{U} / \mathrm{ml})$ and $5 \mu \mathrm{l}$ of extracted DNA, and ultra pure $\mathrm{H}_{2} \mathrm{O}$ were used in a $50 \mu 1$ reaction. Amplification conditions were as described by Sangioni et al. (2005) and Horta et al. (2007). As positive control, DNA from Rickettsia parkeri strain NOD was used, and for the negative control, sterilized distilled water was used.

The amplified products were visualized in $1.5 \%$ agarose gel stained with ethidium bromide (SAMBROOK; FRITSCH; MANIATIS, 1989). Amplification products with the expected sizes were submitted for direct sequencing using an ABI Prism 3100 Genetic Analyzer (Applied Biosystems/Perking Elmer, California, USA) and sequences were submitted to BLAST (Basic Local Alignment Search Tool) to determine similarity to other Rickettsia spp.

\section{Statistical analysis}

An epidemiological questionnaire was used examining the variables: age and sex of humans and animals; interval of residence in the area; the presence of ciliary forest; and the presence of ticks and activities to control ticks on animals. To evaluate these variables, the Chi-Square test or the Fisher Exact test and the Odds Ratio calculation with confidence intervals of $95 \%$ were used. Calculations were determined with Epiinfo 6 program (CDC/Atlanta).

\section{Ethics committees}

The Project was approved by the Ethics Committees of the Universidade Estadual de Londrina for Animal Experimentation ( $\left.\mathrm{n}^{\circ} 82 / 2006\right)$ and for Human Subjects ( $\left.\mathrm{n}^{\circ} 124 / 07\right)$.

\section{Results}

\section{Indirect Immunofluorescence assay (IFA)}

The results of serological tests are shown in Tables 1 and 2. In area 1, when $R$. rickettsii was used as antigen, $21(24.0 \%)$ of 88 human sera had titers $\geq 64$. Of these, 10 had titers of 64,7 of 128,3 of 256 and 1 of 1024 . Among the 19 horse samples, $10(52.6 \%)$ were positive. Of these, 1 had an endpoint titer of 64, 6 of 128, and 3 had titers of 256. Of the 83 dog sera, 19 (22.9\%) were positive with endpoints titers varying from 64 to 1024 . When $R$. parkeri was used as antigen, $14(16.0 \%)$ of the 88 human sera had titers ranging from 64 to 1024; of 19 horse sera, $4(21.0 \%)$ had titers of 64 ; and of 83 dog sera, $15(18.1 \%)$ were positive, 1 at 64,4 at 128,6 at 512 and 3 at 1024 .

In area 2, among 138 human sera, 14 (10.1\%) were positive to $R$. rickettsii antigen. Of these, 5 had titers of 64,8 of 128 and 1 of 256 . From 18 horses, just $1(5.5 \%)$ was positive with endpoint titer of 128 . Of 90 dog sera, 12 (13.3\%) were positive, with endpoints titers of 64 in 2, 1 at 128, 3 at 256, 4 at 512, 1 at 1024 and 1 at 2048. For $R$. parkeri, 6 humans $(4.3 \%)$ were positive with titers ranging from 64 to 256 ; just 1 horse $(5.5 .0 \%)$ was seroreactive with a titer of 128 ; and $11(12.2 \%)$ dogs were positive, 4 with titers of 128,1 at 256, 4 at 512 and 2 at 2048. 
Table 1. Comparison of IFA endpoint titers obtained from human $(\mathrm{H})$ and equine $(\mathrm{E})$ sera using $R$. rickettsii and $R$. parkeri antigens, at two rural localities (Alvorada do Sul - Area 1; and Arapongas - Area 2), North Paraná state, Brazil, 2008.

\begin{tabular}{|c|c|c|c|c|c|}
\hline \multicolumn{3}{|c|}{ Area 1} & \multicolumn{3}{|c|}{ Area 2} \\
\hline Sera & R. rickettsii & R. parkeri & Sera & R. rickettsii & R. parkeri \\
\hline H1 & 64 & 64 & $\mathrm{H} 4$ & 128 & 128 \\
\hline H4 & 128 & neg. & H6 & 64 & 64 \\
\hline H5 & 128 & 64 & $\mathrm{H} 10$ & 256 & 256 \\
\hline H6 & 64 & neg. & H11 & 128 & 128 \\
\hline H7 & 64 & neg. & $\mathrm{H} 12$ & 128 & 128 \\
\hline H10 & 128 & neg. & H14 & 128 & neg. \\
\hline H16 & 64 & 64 & H15 & 128 & neg. \\
\hline $\mathrm{H} 21$ & 64 & 128 & H19 & 128 & neg. \\
\hline $\mathrm{H} 22$ & 64 & neg. & H35 & 128 & neg. \\
\hline $\mathrm{H} 25$ & 64 & 64 & H37 & 64 & neg. \\
\hline H32 & 64 & 64 & H63 & 128 & neg. \\
\hline H51 & 64 & 64 & H64 & 64 & neg. \\
\hline H52 & 1024 & 1024 & H116 & 64 & neg. \\
\hline H57 & 256 & neg. & H119 & 64 & 64 \\
\hline H58 & 128 & 128 & & & \\
\hline H62 & 256 & 256 & & & \\
\hline H66 & 128 & 64 & & & \\
\hline H72 & 256 & 256 & & & \\
\hline H82 & 64 & 64 & & & \\
\hline H87 & 128 & neg. & & & \\
\hline H90 & 128 & 128 & & & \\
\hline H-total* & 21/88 (24.0) & 14/88 (16.0) & H-total* & 14/138 (10.1) & $6 / 138(4.3)$ \\
\hline E1 & 128 & 64 & E29 & 128 & 128 \\
\hline E3 & 128 & 64 & & & \\
\hline E6 & 128 & neg. & & & \\
\hline E8 & 64 & neg. & & & \\
\hline E10 & 256 & 64 & & & \\
\hline E11 & 128 & neg. & & & \\
\hline E13 & 256 & neg. & & & \\
\hline E14 & 128 & neg. & & & \\
\hline E16 & 128 & 64 & & & \\
\hline E19 & 256 & neg. & & & \\
\hline E-total* & $10 / 19(52.6)$ & $4 / 19(21.0)$ & E-total* & $1 / 18(5.5)$ & $1 / 18(5.5)$ \\
\hline
\end{tabular}

Total: No. positives/No. tested (\% positive). 
Among humans with serological reactions to had a higher geometric mean titer for $R$. rickettsii either $R$. rickettsii or $R$. parkeri, the geometric mean (147) than for $R$. parkeri (64), and dogs from both titers were similar in both areas (area 1, 112 vs. 110; areas had a higher titer to R. parkeri (388 vs. 191 in area 2, 105 vs. 114). In contrast, horses from area 1 area 1; 374 vs. 323 in area 2).

Table 2. Comparison of IFA endpoint titers obtained from dog sera using $R$. rickettsii and $R$. parkeri antigens, at two rural localities (Alvorada do Sul - Area 1; and Arapongas - Area 2), North Paraná state, Brazil, 2008.

\begin{tabular}{|c|c|c|c|c|c|}
\hline \multicolumn{3}{|c|}{ Area 1} & \multicolumn{3}{|c|}{ Area 2} \\
\hline Sera & R. rickettsii & R. parkeri & Sera & R. rickettsii & R. parkeri \\
\hline D12 & 128 & 512 & D113 & 64 & neg. \\
\hline D15 & 128 & 512 & D124 & neg. & 128 \\
\hline D18 & 64 & 64 & D149 & 512 & 512 \\
\hline D20 & 256 & 2048 & D170 & 256 & 256 \\
\hline D21 & 256 & 512 & D174 & 2048 & 2048 \\
\hline D24 & 64 & neg. & D175 & 512 & 512 \\
\hline D29 & 128 & 128 & D176 & 256 & 512 \\
\hline D35 & 1024 & 1024 & D178 & 128 & 128 \\
\hline D50 & 64 & neg. & D180 & 1024 & 2048 \\
\hline D52 & 64 & neg. & D182 & 512 & 512 \\
\hline D65 & 512 & 512 & D185 & 256 & 128 \\
\hline D69 & 1024 & 1024 & D187 & 512 & 128 \\
\hline D70 & 1024 & 1024 & D190 & 64 & neg. \\
\hline D71 & neg. & 128 & & & \\
\hline D72 & 256 & 512 & & & \\
\hline D73 & neg. & 128 & & & \\
\hline D74 & 256 & 512 & & & \\
\hline D75 & 512 & neg. & & & \\
\hline D82 & 128 & 128 & & & \\
\hline D94 & 64 & neg. & & & \\
\hline D99 & 64 & neg. & & & \\
\hline D-total* & 19/83 (22.9) & $15 / 83(18.1)$ & D-total* & $12 / 90(13.3)$ & $11 / 90(12.2)$ \\
\hline
\end{tabular}

Total: No. positives/No. tested (\% positive).

Ticks collected and PCR

From a total of 101 ticks collected in area 1, 67 were found parasitizing dogs and 34 were on horses. Of the ticks from dogs, 21 were identified as
Amblyomma ovale, 1 as Amblyomma cajennense and 45 as Rhipicephalus sanguineus. All ticks collected from horses were identified as $A$. cajennense. In area 2 a total of 30 ticks were collected from dogs and horses. Of these, 19 A. ovale and $10 R$. sanguineus were found 
parasitizing dogs and just $1 \mathrm{~A}$. cajennense on a horse.

All ticks collected from the animals were tested by PCR, and only 7 A. ovale ticks contained Rickettsia gltA. Figure 1 shows 4 A. ovale positive samples, as well reaction controls). Among these, 3 were from area 1 and 4 were from area 2. However, when these samples were subjected to spotted fever group ompA PCR, all were negative. The gltA amplicons were sequenced; all showed identity with Rickettsia bellii (GenBank number FJ789813).

Figure 1. Detection of a fragment of the rickettsial gene gltA by PCR in Amblyomma ovale in $1.5 \%$ agarose gel. (1) 123-bp DNA size marker ladder; (2) Positive control; $(3,4,5,6)$ positive samples extracted from A. ovale; (7) negative sample; (8) nucleic acid extraction negative control and (9) PCR negative control.

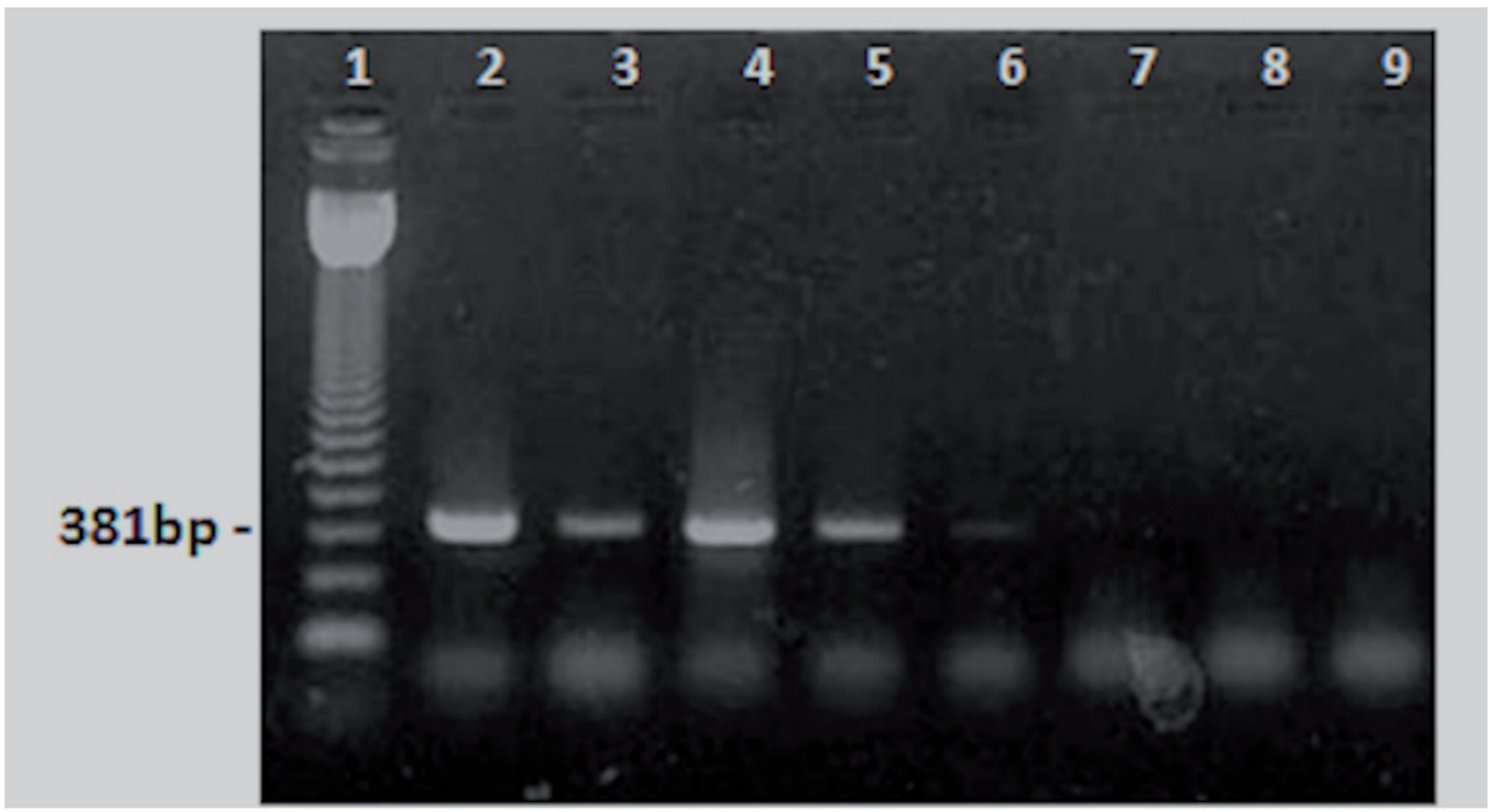

\section{Epidemiological questionnaire and statistics}

Tables 3 and 4 show the variables for the areas 1 and 2 with statistically significant associations in the epidemic questionnaires given to each human subject who provided blood and from each owner from which an animal blood sample was obtained.

Epidemiological variables were examined with respect to rickettsial seropositivity. In Area 1, among horses with $R$. rickettsii antibodies, a significant association was obtained for animals for which tick control was reported. Of 8 animals for which tick control treatment was not used, 7 were $R$. rickettsii seropositive $(\mathrm{p}=0.022)$. For humans, $R$. rickettsii seropositivity was significantly associated with the presence of a seropositive horse $(\mathrm{p}=0.011)$. Among 16 humans who owned a horse, 8 were $R$. rickettsii seropositive. For $R$. parkeri seropositive dogs, there was a significant association when the presence of ticks was reported $(\mathrm{p}=0.017)$. Of 65 dogs for which contact with ticks was reported, 15 were seropositive for $R$. parkeri. Of 10 horses for which tick control efforts were reported, none were seropositive $(\mathrm{p}=0.022)$. No significant associations were identified for any variable with regard to R. parkeri seropositivity in human sera (Table 2).

In area 2, the only significant association 
was contact with ciliary forests in $R$. rickettsii and $R$. parkeri seropositive dogs. Of 20 dogs, $8 R$. rickettsii seropositives and $4 R$. parkeri seropositives were living near ciliary forest areas $(\mathrm{p}=0.025$ and $\mathrm{p}=0.012$ ). No significant associations were found for humans or horses in this area (Table 3).

\section{Discussion}

The present study was conducted in rural areas located in North Paraná state, Brazil, a region assumed as nonendemic, since no cases of BSF nor has rickettsia infection in ticks has been reported before. Our serologic tests provide evidence that one or more spotted fever group Rickettsia species may be present and could potentially infect humans and domestic animals in these localities. Sera from humans, horses and dogs reacted with $R$. rickettsii, $R$. parkeri, or both in differing intensities and titers depending on the serum source and the area studied. Serologic reactions with $R$. rickettsii, the agent of BSF in Southeast Brazil, was more frequent and of higher titers in humans and horses; however, dogs had more frequent and higher titer serological responses to $R$. parkeri (Tables 1 and 2).

The seroprevalence in humans from Alvorada do Sul (area 1) and Arapongas (area 2) Counties were, respectively, $24.0 \%$ and $10.1 \%$, using $R$. rickettsii antigen. The rate found for area 1 is considered high because there are no symptomatic cases of BSF reported in this area. Similar studies conducted in endemic and nonendemic areas have shown lower seroprevalence rates. In an endemic area of Minas Gerais state, Lemos, Machado e Coura (1994) found a seroprevalence of $7.14 \%$, and in Mogi das Cruzes County, state of São Paulo, Pinter et al. (2008) detected $R$. rickettsii antibodies in $2.8 \%$ of human sera. Moreover, Horta et al. (2007), showed seroprevalence rates varying from $10 \%$ to $19 \%$, in four endemic areas of São Paulo municipality, and in a nonendemic area the same authors found $17.8 \%$ seropositivity.

Table 3. Significantly associated epidemiological variables among seropositive humans, horses, or dogs for R. rickettsii and $R$. parkeri antibodies, in Alvorada do Sul (Area 1), North Paraná state, Brazil.

\begin{tabular}{|c|c|c|c|c|c|c|}
\hline Antigen & Samples & Variables & Option & Positives/Total (\%) & $p$ value & OR $(95 \%$ CI $)$ \\
\hline \multirow[t]{7}{*}{ R. rickettsii } & Dog & - & - & - & - & - \\
\hline & Horse & Tick control & & & & \\
\hline & & efforts & yes & $3 / 10$ & $0.022 *$ & $0.06(0.00-1.02)$ \\
\hline & & & no & $7 / 8$ & & \\
\hline & Human & seropositive & & & & \\
\hline & & horse & yes & $8 / 16$ & $0.011^{*}$ & $4.54(1.24-16.92)$ \\
\hline & & & no & $13 / 72$ & & \\
\hline \multirow[t]{7}{*}{ R. parkeri } & Dog & Presence & & & & \\
\hline & & of ticks & yes & $15 / 65$ & 0.017 & - \\
\hline & & & no & $0 / 18$ & & \\
\hline & Horse & Tick control & & & & \\
\hline & & & yes & $0 / 10$ & $0.022 *$ & - \\
\hline & & & no & $4 / 8$ & & \\
\hline & Human & - & - & - & - & - \\
\hline
\end{tabular}

* Fisher Exact Test. 
Table 4. Significantly associated epidemiological variables among seropositive humans, horses, or dogs for $R$. rickettsii and $R$. parkeri antibodies, in Arapongas (Area 2), North Paraná state, Brazil.

\begin{tabular}{llccccc}
\hline Antigen & samples & Variables & Option & Positives/Total (\%) & p value & OR (95\% CI) \\
\hline R. rickettsii & Dog & Ciliary Forest contact & yes & $8 / 41$ & 0.025 & $6.0(1.10-32.81)$ \\
& & & no & $4 / 49$ & & - \\
& Horse & - & - & - & - & - \\
\multirow{2}{*}{ R. parkeri } & Human & - & - & - & - & \\
& Dog & Ciliary forest & & & & \\
& & localization & $<100 \mathrm{~m}$ & $4 / 10$ & $0.012 * 8.11(1.40-48.30)$ \\
& & & $>100 \mathrm{~m}$ & $6 / 80$ & & - \\
& Horse & - & - & - & - & - \\
\hline
\end{tabular}

* Fisher Exact Test.

The high rate of human seropositivity found in our study conducted in a nonendemic area for BSF is similar to other studies. Considering that humans and their horses always lived together in and had similar seroprevalences, the high rates could be explained by frequent contact of humans with ticks that ordinarily parasitize horses. The discrepancy between high seroprevalence and the lack of clinical cases suggests that there are mild or subclinical cases of BSF or infections/immune stimulation by other spotted fever group rickettsiae with low pathogenicity.

Inhorses fromarea 1, reactivity against $R$. rickettsii was $52.6 \%$, although this was not significantly associated with the variable "contact with ticks," the percentage of owners who reported contact with ticks was almost $90 \%$. This seroprevalence is high, considering that the study was conducted in an area that never reported BSF. Other studies showed that the percentage of seropositive horses in an endemic region ranged from $77.3 \%$ (HORTA et al., 2004) and $57.1 \%$ to $80 \%$ (SANGIONI et al., 2005). In contrast, seropositivity to $R$. rickettsii in area 2 was $10.1 \%$, significantly lower than in area 1 , and closer to the $19 \%$ seropositive rate that Horta et al. (2007) found in a nonendemic region.

The high seropositive rate in horses from North Paraná state supports Sangioni et al. (2005) who suggest that surveys of horse sera are useful for BSF surveillance in areas where humans are exposed to A. cajennense. Horses are the primary host for $A$. cajennense and in places with heavy infestations, humans as well as other animals can become secondary hosts (LABRUNA et al., 2001; HORTA et al., 2007; PINTER et al., 2008). From this point of view, our study using horses as sentinels for BSF suggests increased risk for humans and dogs in the area 1 .

Of interest, seropositivity to $R$. rickettsii in dogs in area 1 was $22.9 \%$, similar to the Pirassununga region in São Paulo state, a nonendemic area for BSF where there has never been a case of BSF (HORTA et al., 2007). In area 2, seropositivity in dogs was $13.3 \%$, almost half of that in the area 1. Such a difference could be due to the lower abundance of ticks in area $2(41 \%)$ than in area $1(78 \%)$. In addition, dogs from area 1 had more contact with forested areas where they likely acquired $A$. ovale. In area $2, \operatorname{dogs}$ received better care from their owners and were usually restricted from roaming away from their owner's homes reducing likely encounters with ticks. In contrast, dogs from area 1 always were often observed walking freely through the neighborhood.

A. ovale usually parasitizes wild animals but it 
is possible to find these ticks on dogs in rural areas (ARAGÃO; FONSECA, 1961). The occurrence of $A$. ovale parasitizing humans is described in an Atlantic rainforest reserve in Southeastern Brazil (SZABÓ et al., 2006). We observed A. ovale parasitizing dogs in the both studied areas, raising the question as to whether $A$. ovale could have been infected by and transmitted $R$. parkeri or a similar rickettsia in Paraná State as an explanation for some of the high titers observed in dogs, since one strain of $R$. parkeri has been reported infecting $A$. ovale ticks in the state of São Paulo, southeastern Brazil (SABATINI et al., 2010).

In humans, $R$. parkeri is described as a less severe infection than RMSF and it is possible that it could account for the lack of recognized BSF in some cities including in nonendemic areas of São Paulo where serological studies suggest infection should exist (HORTA et al., 2007; SILVEIRA et al., 2007), and mostly important, because clinical infection due to $R$. parkeri has been reported in two different regions of Brazil (SPOLIDORIO et al., 2010, SILVA et al., 2011).

In contrast, humans and in particular, horses had more serological evidence of infection by $R$. rickettsii or very closely related species. No BSF cases have been described in these study sites and no attempt was made to relate clinical findings in humans to seropositivity. Therefore it is necessary to conduct further studies, perhaps including other rickettsial antigens, to better identify which Rickettsia species is eliciting these serological responses.

Finally, we attempted to survey the Rickettsia species infecting ticks in the study sites. We observed only $R$. bellii in A. ovale collected from dogs from the 2 areas. $R$. bellii is frequently found in various tick species in Brazil (HORTA et al., 2004; LABRUNA, 2009). Our findings are in agreement with another study in Rondonia where $A$. ovale infected with $R$. bellii were found. Although $R$. bellii commonly infects ticks, this basal group Rickettsia species has never been described as pathogenic for humans, horses or dogs (HORTA et al., 2004; LABRUNA et al. 2007c). These findings are supported by studies showing that dogs parasitized with $R$. belliiinfected ticks were seronegative to $R$. bellii by IFA (PINTER et al., 2008). In contrast, Pacheco et al. (2007) provided possible serological evidence of infection of capybaras by $R$. bellii. Regardless, the results of the tick studies conducted here leave open the question of which species could be involved in inducing the high rates of seropositivity observed in humans, horses, and dogs in northern Parana State.

This epidemiological study in the State of Paraná shows the high seroprevalence of spotted fever group rickettsia infection among humans, horses, and dogs and suggests the potential risk for human BSF in this area. However, the uncertainty of serological testing in the spotted fever group rickettsiae leaves open for further investigation the question as to which species is causing the serological reactions and whether there is any clinical disease in humans or domestic animal populations that sustain infection.

\section{Acknowledgements}

We wish to thank the CNPq for fellowship and financial support and Movimento dos Sem Terra (MST) for the arrangements to work into the rural communities.

\section{References}

ARAGÃO, H.; FONSECA, F. Notas de ixodologia. VIII. Lista e chave para os representantes da fauna ixodológica brasileira. Memórias do Instituto Oswaldo Cruz, Rio de Janeiro, v. 59, n. 2, p. 115-129, 1961.

CHOMKZYNSK, P. A reagent for the single step simultaneous isolation of RNA, DNA and proteins from cell and tissue samples. Biotechniques, v. 15, n. 3, p. 532337, 1993.

DUMLER, J. S.; BARBET, A. F.; BEKKER, C. P.; DASCH, G. A.; PALMER, G. H.; RAY, S. C.; RIKIHISA, Y.; RURANGIRWA, F. R. Reorganization of genera in the families Rickettsiaceae and Anaplasmataceae in the order Rickettsiales: unification of some species of Ehrlichia with Anaplasma, Cowdria with Ehrlichia and 
Ehrlichia with Neorickettsia, descriptions of six new species combinations and designation of Ehrlichia equi and 'HGE agent' as subjective synonyms of Ehrlichia phagocytophila. International Journal of Systematic and Evolucinary Microbiology, UK, v. 51, n. 6, p. 2145-2165, 2001.

FREITAS, M. C. D. O.; GRYCAJUK, M.; MOLENTO, M. B.; BONACIN, J.; LABRUNA, M. B.; PACHECO, R. C.; MORAES-FILHO, J.; DECONTO, I.; BIONDO, A. W. Brazilian spotted fever in cart horses in a nonendemic area in Southern Brazil. Revista Brasileira de Parasitologia Veterinária, Jaboticabal, v. 19, n. 2, p. 1-2, 2010.

GALVÃO, M. A. M.; CALIC, S. B.; CHAMONE, C. B.; MAFRA, C. L.; CESARINO FILHO, G.; OLANO, J. P.; WALKER, D. H. Spotted fever rickettsiosis in Coronel Fabriciano, Minas Gerais State. Revista da Sociedade Brasileira de Medicina Tropical, Uberaba, v. 36, n. 4, p. 479-481, 2003.

GUEDES, E.; LEITE, R. C.; PRATA, M. C.; PACHECO, R. C.; WALKER, D. H.; LABRUNA, M. B. Detection of Rickettsia rickettsii in the tick Amblyomma cajennense in a new Brazilian spotted fever-endemic area in the state of Minas Gerais. Memórias do Instituto Oswaldo Cruz, Rio de Janeiro, v. 100, n. 8, p. 841-845, 2005.

GUIMARÃES, J. H.; TUCCI, H. E. C.; BARROSBATTESTI, D. M. Ectoparasitos de importância veterinária. Editora Plêiade: São Paulo, 2001.

HOOGSTRAAL, H. Argasid and Nuttallielid ticks as parasites and vectors. Advances in Parasitololgy, v. 1, p. 135-238, 1985.

HORTA, M. C.; LABRUNA, M. B.; PINTER, A.; LINARDI, P. M.; SCHUMMAKER, T. T. S. Rickettsia infection in five areas of the state of São Paulo, Brazil. Memórias do Instituto Oswaldo Cruz, Rio de Janeiro, v. 102, n. 7, p. 793-801, 2007.

HORTA, M. C.; LABRUNA, M. B.; SANGIONI, L. A.; VIANNA, M. C. B.; GENNARI, S. M.; GALVÃO, M. A. M.; MAFRA, C. L.; VIDOTTO, O.; SCHUMAKER, T. T. S.; WALKER, D. H. Prevalence of antibodies to Spotted Fever Group Rickettsiae in humans and domestic animals in a state of São Paulo, Brazil: serologic evidence for infection by Rickettsia rickettsii and another Spotted Fever Group Rickettsia. American Journal of Tropical Medicine and Hygiene, v. 71, n. 1, p. 93-97, 2004.

LABRUNA, M. B. Ecology of Rickettsia in South America. Annals of the New York Academy of Science, New York, v. 1166, p. 156-166, 2009.

LABRUNA, M. B.; HORTA, M. C.; AGUIAR, D. M.; CAVALCANTE, G. T.; PINTER, A.; GENNARI, S. M.;
CAMARGO, L. M. A. Prevalence of Rickettsia infection in dogs from the urban and rural areas of Monte Negro Municipality, western Amazon, Brazil. Vector Borne and Zoonoses Diseases, v. 7, n. 2, p. 249-255, 2007c.

LABRUNA, M. B.; PACHECO, R. C.; NAVA, S.; BRANDÃO, P. E.; RICHTZENHAIN, L. J.; GUGLIELMONE, A. A. Infection by Rickettsia bellii and Candidatus "Rickettsia amblyommii" in Amblyomma neumanni from Argentina. Microbial Ecology, v. 54, n. 1, p. 126-133, 2007a.

LABRUNA, M.B.; PACHECO, R.C.; RICHTZENHAIN, L. J.; SZABO, M. P. Isolation of Rickettsia rhipicephali and Rickettsia bellii from ticks Haemaphysalis juxtakochi in the state of São Paulo, Brazil. Applied Enviromental Microbiology, v. 73, n. 3, p. 869-873, 2007 b.

LABRUNA, M. B.; WHITWORTH, T; BOUYER, D. H.; MCBRIDE, J. W.; CAMARGO, L. M. A.; CAMARGO, E. P.; POPOV, V.; WALKER, D. H. Rickettsi belli and Rickettsia amblyommi in Amblyomma ticks from the state of Rondonia, Western Amazon, Brazil. Journal of Medical Entomology, v. 41, p. 1073-1081, 2004.

LABRUNA, M. B.; CAMARGO, L. M.; CAMARGO, E. P.; WALKER, D. H. Detection of a spotted fever group Rickettsia in the tick Haemaphysalis juxtakochi in Rondônia, Brazil. Veterinary Parasitology, Amsterdam, v. 127, n. 2, p. 69-174, 2005.

LABRUNA, M. B.; KERBER, C. E.; FERREIRA, F.; FACCINI, J. L. H.; DE WAAL, D. T.; GENNARI, S. M. Risk factors to tick infestations and their occurrence on horses in the state of São Paulo, Brazil. Veterinary Parasitology, Amsterdam, v. 97, n. 1, p. 1-14, 2001.

LEMOS, E. R. S.; ALVARENGA, F. B. F.; CINTRA, M. L.; RAMOS, M. C.; PADDOCK, C. D.; FEREBEE, T. L.; ZAKI, S. R.; FERREIRA, F. C. C.; RAVAGNANI, R. C.; MACHADO, R. D.; GUIMARÃES, M. A. A. M.; COURA, J. R. Spotted fever in Brazil: a seroepidemiological study and description of clinical cases in an endemic area in the state of São Paulo. American Journal of Tropical Medicine and Hygiene, v. 65, n. 4, p. 329-334, 2001.

LEMOS, E. R. S.; MACHADO, R. D.; COURA, J. R. Rocky mountain fever in an endemic area in Minas Gerais, Brazil. Memórias do Instituto Oswaldo Cruz, Rio de Janeiro, v. 89, p. 479-501, 1994.

LEMOS, E. R. S.; MACHADO, R. D.; COURA, J. R.; GUIMARÃES, M. A. A.; FREIRE, N. M. S.; AMORIM, M.; GAZETA, G. S. Espidemiological aspects of the Brazilian spotted fever: seasonal activity of ticks collected in an endemic area in São Paulo, Brazil. Revista da Sociedade Brasileira de Medicina Tropical, Uberaba, 
v. 30, n. 3, p. 181-185, 1997.

McDADE, J. E.; NEWHOUSE, V. F. Natural history of Rickettsia rickettsii. Annual Review of Microbiology, v. 40, p. 287-309, 1986.

PACHECO, R. C.; HORTA, M. C.; MORAES, J. F.; ATAliBA, A. C.; PINTER, A.; LABRUNA, M. B. Rickettsial infection in capybaras (Hydrochoerus hydrochaeris) from São Paulo, Brazil: serological evidence for infection by Rickettsia bellii and Rickettsia parkeri. Biomedica, v. 27, n. 3, p. 364-371, 2007.

PINTER, A.; HORTA, M. C.; PACHECO, R. C.; FILHO, J. M.; LABRUNA, M. B. Serosurvey of Rickettssia spp. in dogs and humans from an endemic area for Brazilian spotted fever in the state of São Paulo, Brazil. Cadernos de Saúde Pública, v. 24, n. 2, p. 247-252, 2008.

PINTER, A.; LABRUNA, M. B. Isolation of Rickettsia rickettsii and Rickettsia bellii in cell culture from the tick Amblyomma aureolatum in Brazil. Annals of the New York Academy of Sciences, New York, v. 1078, p. 523529, 2006.

RAOULT, D.; ROUX, V. Rickettsioses as paradigmis of new or emerging infectious diseases. Clinical Microbiology Reviews, v. 10, p. 694-719, 1997.

REGNERY, R. L.; SPRUILL, C. L.; PLIKAYTIS, B. D. Genotypic identification of Rickettsiae and estimation of intraspecies sequence divergence for portions of two Rickettsial genes. Journal Bacteriology, v. 173, n. 5, p. 1576-1589, 1991.

SABATINI, G. S.; PINTER, A.; NIERI-BASTOS, F. A.; MARCILI, A.; LABRUNA, M. B. Survey of ticks (Acari: Ixodidae) and their rickettsia in an Atlantic rain forest reserve in the State of São Paulo, Brazil. Journal of Medical Entomology, v. 47, n. 5, p. 913-916, 2010.

SAITO, T.; CUNHA, F. N.; PACHECO, R. C.; FERREIRA, F.; PAPPEN, F.; FARIAS, N.; LARSSON, C.; LABRUNA, M. B. Canine infection by rickettsiae in southern Brazil. American Journal of Tropical Medicine and Hygiene, v. 79, n. 1, p. 102-108, 2008.

SAMBROOK, J.; FRITSCH, E. F.; MANIATIS, T. Molecular cloning: a laboratory manual. $2^{\text {nd }}$ ed. Cold Spring Harbor, New York: Cold Spring Harbor Laboratory, 1989.

SANGIONI, L. A.; HORTA, M. C.; VIANNA, M. C. B.; GENNARI, S. M.; SOARES, R. M.; GALVÃO, M. A. M.; SCHUMAKER, T. T. S.; FERREIRA, F.; VIDOTTO, O.; LABRUNA, M. B. Rickettsial infection in animals and brazilian spotted fever endemicity. Emerging Infectious Diseases, v. 11, p. 265-270, 2005.

SILVA, N.; EREMEEVA, M. E.; ROZENTAL, T.;
RIBEIRO, G. S.; PADDOCK, C. D.; RAMOS, E. A.; FAVACHO, A. R.; REIS, M. G.; DASCH, G. A.; DE LEMOS, E. R.; KO, A. I. Eschar-associated spotted fever rickettsiosis, Bahia, Brazil. Emerging Infectious Diseases, v. 17, n. 2, p. 275-278, 2011.

SILVEIRA, I.; PACHECO, R. C.; SZABÓ, M. P. J.; RAMOS, H. G. C.; LABRUNA, M. B. First report of Rickettsia parkeri in Brazil. Emerging Infectious Diseases, v. 13, n. 7, p. 1111-1113, 2007.

SPOLIDORIO, M. G.; LABRUNA, M. B.; MANTOVANI, E.; BRANDAO,P.E.; RICHTZENHAIN, L. J.; YOSHINARI, N. H. Novel spotted fever group rickettsiosis, Brazil. Emerging Infectious Diseases, v. 16, n. 3, p. 521-523, 2010 .

SZABÓ, M. P.; LABRUNA, M. B.; CASTAGNOLLI, K. C.; GARCIA, M. V.; PINTER, A.; VERONEZ, V. A.; MAGALHÃES, G. M.; CASTRO, M. B.; VOGLIOTTI, A. Ticks (Acari: Ixodidae) parasitizing humans in an Atlantic rainforest reserve of Southeastern Brazil with notes on host suitability. Experimental Applied Acarology, v. 39, n. 3/4, p. 339-346, 2006.

TOLEDO, R. S.; TAMEKUN, K.; SILVA FILHO, M. F.; HAYDU, V. B.; BARBIERI, A. R. M.; HILTEL, A. C.; PACHECO, R.; LABRUNA, M. B.; DUMLER, J. S.; VIDOTTO, O. Infection by spotted fever Rickettsiae in people, dogs, horses and ticks in Londrina, Parana State, Brazil. Zoonoses and Public Health, v. 58, n. 6, p. 416423, 2011.

TRAVASSOS, J.;VALLEJO-FREIRE,A.Comportamento de alguns cavídeos (Cavia aperea e Hydrochoerus capybara) às inoculações experimentais do vírus da febre maculosa. Possibilidade desses cavídeos representarem o papel de depositários transitórios do vírus na natureza. Memórias do Instituto Butantã, v. 15, p. 73-86, 1942. 